\title{
EFFECTS OF A.C.T.H. ON A CASE OF TUBERCULOUS MENINGITIS
}

BY

\author{
I. M. LECK \\ From Walsall General Hospital
}

(RECEIVED FOR PUBLICATION DECEMBER 11, 1956)

Although there are published references to over 200 cases of tuberculous meningitis treated with A.C.T.H., cortisone, or hydrocortisone, very few authors describe the effects of these hormones on patients with over $1 \%$ protein in the C.S.F. Kendig, Choy and Johnson (1956) gave cortisone to a child during two periods when her C.S.F. protein was above $5 \mathrm{~g}$. \%; the protein content fell below $1 \mathrm{~g}$. within a fortnight each time, and increased again when the first course of cortisone was stopped. Paraf, Paraf and Rapaud (1954) gave A.C.T.H. to patients whose C.S.F. contained up to $3 \mathrm{~g}$. protein/ $100 \mathrm{ml}$., but their results, although encouraging, were only reported very briefly.

\section{Case Report}

In November, 1952, a girl aged 22 months was admitted to the Manor Hospital, Walsall, with tuberculous meningitis. She was given 45 daily intrathecal injections of streptomycin and a six months' course of P.A.S. and intramuscular streptomycin. She recovered completely, and remained well until nearly 4 years old, when she was admitted to the Walsall General Hospital with a history of fretfulness, headache, vomiting and constipation for a few days. On admission, on December 13, 1954, she was fretful, with slight neck stiffness but no other clinical abnormality. Temperature (normal on admission) was between 99 and $100^{\circ} \mathrm{F}$. for most of her first two weeks in hospital. A chest radiograph showed calcification at the right hilum, and a calcified Ghon focus in the left lung which had also been noticed two years before. The C.S.F. contained: white cells, 100/c.mm. ( $70 \%$ lymphocytes), protein, $160 \mathrm{mg} . / 100 \mathrm{ml}$., glucose, $31 \mathrm{mg} . / 100 \mathrm{ml}$., chlorides, $740 \mathrm{mg} . / 100 \mathrm{ml}$. (as Na Cl.), Z.-N. stain, acid-fast bacilli present. Tuberculous meningitis was again diagnosed, and the child was given isoniazid (50 mg. eight-hourly) from December 15, 1954, to July 21,1955 , and intramuscular streptomycin $(350 \mathrm{mg}$. twice a day) from December 15 to June 13. Her clinical condition improved considerably during her first month in hospital, and after two weeks there her temperature became normal apart from rises to $99-99 \cdot 4^{\circ} \mathrm{F}$. once or twice each week.

The C.S.F. was examined weekly. As is shown by the graph, during the first month it became more abnormal; and for three periods between the fifth and fifteenth weeks in hospital it was yellow, with protein about 2 g. \%. A course of A.C.T.H. was begun during each of these periods. Within four to 16 days of the start of each course, the C.S.F. protein content fell to 100 $300 \mathrm{mg}$. \%, and its fall was especially rapid during the first course (when the initial daily dose of A.C.T.H. was 80 units, not 20 units as in the other two courses). Each time A.C.T.H. was stopped, the C.S.F. protein content increased again within one to six days, although after the third and longest course this increase was relatively small. The protein content increased again when streptomycin

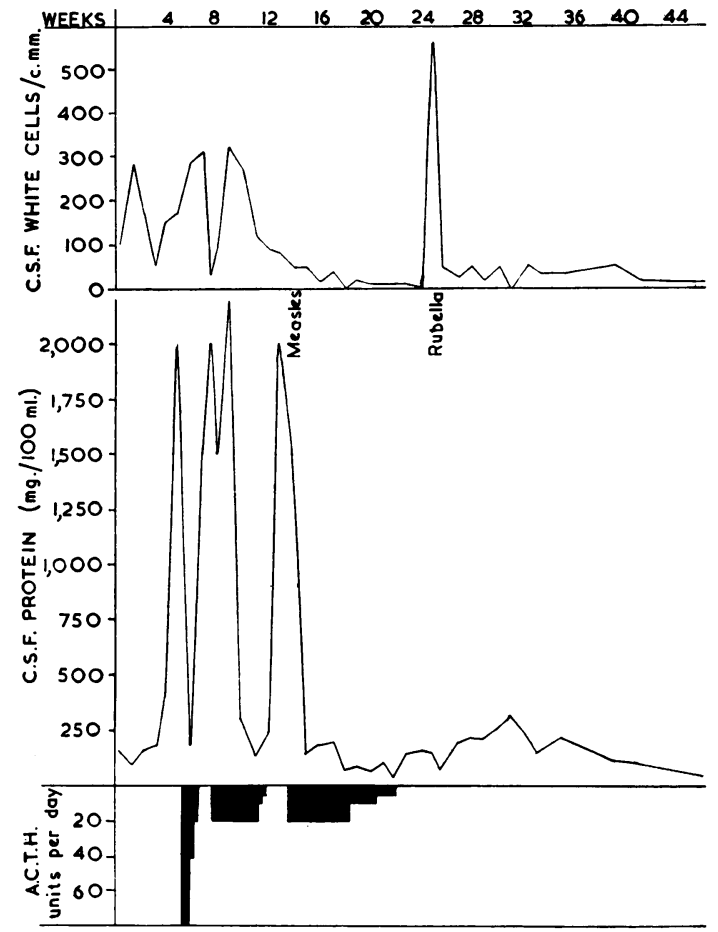

FIG.-C.S.F. Cells and Protein before, during and after treatment with A.C.T.H. 
was discontinued, but did not then exceed $320 \mathrm{mg}$. \%, and finally fell spontaneously to normal.

The other contents of the C.S.F. did not fluctuate as widely as the protein. The cells (chiefly lymphocytes) were most numerous $(320 / \mathrm{c} . \mathrm{mm}$.) during the second great increase of protein, apart from an isolated rise to $560 / \mathrm{c} . \mathrm{mm}$. on June 8 (during an attack of rubella). Forty-six weeks after admission the C.S.F. was normal, except for 16 lymphocytes/c.mm.

The child's clinical condition bore little relation to these changes in the C.S.F., although during the second great increase of protein her temperature was slightly elevated in the evenings. She had measles after 13 weeks and rubella after 25 weeks in hospital. Otherwise, after the first few weeks she kept very fit. While receiving A.C.T.H. she was euphoric and gained weight rapidly, but her weight fell again after A.C.T.H. was stopped. She was sent for convalescence on July 21 and home on November 24, 1955. When last seen, on May 9, 1956, she seemed quite healthy.

\section{Comment}

Three times this child's C.S.F. protein content fell when A.C.T.H. was given and rose when it was stopped. As A.C.T.H. acts on the adrenals, it seems almost certain that these phenomena were due to the anti-inflammatory action of cortisone. This may have reduced the C.S.F. protein content either by relieving intrathecal block or by suppressing the meningeal reaction to tuberculin. The xanthochromia and very high protein content of the C.S.F. could have been due to block, and cortisone may be able to dissolve the tuberculous exudate which causes block (Shane, Clowater and Riley, 1952).

But as the C.S.F. protein content fell so fast when A.C.T.H. was started and rose so fast when it was stopped, and as the child seemed well and C.S.F. was easily obtained on lumbar puncture throughout, there may have been no block. In that case, as it is apparently an intrathecal hypersensitivity reaction to tuberculin that raises the C.S.F. protein content in tuberculous meningitis (Cairns and Smith, 1952), the exceptional rises in this patient's C.S.F. protein content may have been due to exceptional hypersensitivity to tuberculoprotein caused by one attack of tuberculous meningitis following on another. A.C.T.H. may have reduced the C.S.F. protein content by suppressing this hypersensitivity, and the rise in protein each time A.C.T.H. was stopped may have been due to a revival of hypersensitivity. Similarly, Long and Favour (1950) found that in tuberculinsensitive patients, skin reactivity to tuberculin decreased when A.C.T.H. or cortisone was given, and revived when it was stopped.

If intrathecal block was not present in this case, it was very likely incipient, as a meningeal hypersensitivity reaction intense enough to raise the C.S.F. protein content to $2 \mathrm{~g}$. \% would probably soon produce sufficient exudate to cause block. To avoid this, all patients whose protein content is so high should perhaps be given A.C.T.H. (or cortisone), in the hope that it will disperse any exudate and/or suppress the intrathecal tuberculin reaction by which such exudate may be produced. As this patient's C.S.F. protein content rose rapidly when the first and second courses of A.C.T.H. were stopped, it seems that this may need to be given for two or more months if it is to have a lasting effect.

I am grateful to Dr. J. M. Garvie for permission to report this case and for his very helpful advice.

\section{REFERENCES}

Cairns, H. and Smith, H. V. (1952). In Modern Practice in Tuberculosis, 1st. ed., vol. 2, p. 364. Ed. Sellors, T. H., and Livingstone, J. L. London

Kendig, E. L., Jr., Choy, S. H. and Johnson, W. H. (1956). Amer. Rev. Tuberc., 73, 99 .

Long, J. B. and Favour, C. B. (1950). Bull. Johns Hopk. Hosp., 87, 186.

Paraf, J., Paraf, M. and Rapaud, G. (1954). Bull. Soc. méd. Hôp. Paris, 70, 1165.

Shane, S. J., Clowater, R. A. and Riley, C. (1952). Canad. med. Ass. J., 67, 13 . 